\title{
Isolation and Characterization of Fungi Species Associated with Some Selected Fruits Sold in Gashua Markets, Nigeria
}

\section{Thliza $\mathbf{I A}^{\mathbf{1}^{*}}$, Rose $\mathrm{KL}^{1}$, Mary $\mathrm{AM}^{2}$, Nachabatha $\mathbf{M}^{3}$, Haruna $\mathrm{SS}^{1}$ and Mohammed $\mathbf{A}^{1}$}

${ }^{1}$ Department of Biological Science, Federal University. Gashua. Nigeria, thlizaijai@fugashua.edu.ng

${ }^{2}$ Department of Biological Sciences, Federal University, Kashere, Nigeria

${ }^{3}$ Department of Animal Health and Production Technology, College of Agriculture, Ganye, Nigeria

Thliza IA, Rose KL, Mary AM, Nachabatha M, Haruna SS, Mohammed A 2020 - Isolation and Characterization of Fungi Species Associated with Some Selected Fruits Sold in Gashua Markets, Nigeria. Asian Journal of Mycology 3(1), 446-455, Doi 10.5943/ajom/3/1/15

\begin{abstract}
The study aimed at isolation and characterization of fungi species associated with some selected fruits sold in Gashua markets. A total of forty-five fruits with a proportion of fifteen (five oranges, five bananas and five apples) from each market, labeled and were transported to the laboratory in a clean polythene bag for analysis. The sampled fruits were surface-sterilized for 3 minutes with $1 \%$ Sodium hypochlorite and rinsed using sterile distilled running water three times and cultured on a Potato Dextrose Agar, replicated three times and, were labeled accordingly. The plates were incubated in an inverted position at $26-30^{\circ} \mathrm{C}$ for $5-7$ days. The identification was aided by using the identification keys. A total of eight (8) fungi species were isolated. The maximum percentage of fungi was noticed in apple as $50 \%$, while banana and orange had the same percentage of $24.99 \%$ each. Mucor hiemalis and Rhizopus oligosporus had the highest percentage of $16.67 \%$ each out of the eight (8) fungi species isolated. The high percentage of contamination of apple by fungal species could be attributed to poor hygiene during handling and high exposure to environmental conditions or contaminants.
\end{abstract}

Key words - Citrus sinensis - Malus domestica - Microorganism - Musa sapientum

\section{Introduction}

Fruit refers to the fleshy part of a plant, which may or may not contain seed, and could be eaten in the raw state. The dietary value of fruits in the human diet plays a vital role in sustaining the metabolic processes, which aid in maintaining good health and preventing ailments, such as heart disease and cancer (Dhandevi \& Rajesh 2015, Muhammad et al. 2018). The high dietary nature and nutritional quality of fruits are essential for human nutrition. Fruits are a major source of macro-nutrients such as fibre and micronutrients, such as minerals and vitamin A, B, C, thiamin, riboflavin, B6 niacin, folate A and E (Rickman et al. 2007, Elsayed \& Edrees 2014). Fruits are well known for their antioxidant compounds that protect against oxidative damage caused by free radicals and shown to be effective in preventing retinal diseases, such as muscular degeneration. They are used as nutritional remedies for many patients suffering from different ailments such as diabetes, constipation and stroke (Obeta et al. 2011). 
Sweet orange, scientifically known as Citrus sinensis, belongs to the family Rutaceae (Muhammad et al. 2018). There are three genera and eighteen defined species widely spread throughout the world (Guo \& Deng 2001). Citrus is grown in Nigeria and many other tropical and subtropical regions. In terms of volume in production, citrus ranks after banana as the world's second fruit crop with more than 108 million tons (Piccinelli et al. 2008). Economically, oranges are important fruit crops with an estimated 60 million metric tons produced worldwide as at 2005 for a total value of 9 billion dollars (Muhammad et al. 2018). Out of the total global production, half came from Brazil and the United States of America (Goudeau et al. 2008, Bernardi et al. 2010). The global citrus acreage, according to FAO statistics in 2009, was 9 million hectares with production put at 122.3 million tons, ranking sweet oranges first among all the fruit crops (Bernardi et al. 2010). Citrus sinensis is a major source of vitamins (especially vitamins A, B and C), calcium, potassium, magnesium, iron, chlorine, manganese, zinc, sodium, phosphorous, iodine, folic acid, pectin, beta-carotene, amino acids, fibre, carotenoids, flavonoid, hesperidin, naringenin, and regulatory enzymes (protein kinase $\mathrm{C}$, phosphodiesterase, phospholipase, lipoxygenase, and cyclooxygenase) (USDA-APHIS 2010). The health benefits of the bioactive components of orange range from being an anti-obesity, an anti-oxidant, an anti-inflammatory, improves body immunity and vision, maintain healthy mucus membrane and skin, and regulates the rate of heart and blood pressure (Sinclair et al. 1945, Manthey et al. 2001, Danila et al. 2005, Sohail et al. 2006, Tripoli et al. 2007, Muhammad et al. 2018).

An apple is a sweet, edible fruit produced by Malus domestica, which belongs to the family Rosaceae. The apple fruit is of great nutritive and therapeutic values. Research suggests that apples may reduce the risk of colon cancer, prostate cancer and lung cancer (Zahra 2016). Compared to many other fruits and vegetables, apples contain relatively low amounts of Vitamin $\mathrm{C}$, as well as several other antioxidant compounds (Boyer 2009). The fibre content, while less than in most other fruits, helps to regulate bowel movements, and may thus reduce the risk of colon cancer. They may also help in preventing heart disease, weight loss, and controlling cholesterol, as they do not have any cholesterol, but have fibre, which reduces cholesterol by preventing re-absorption. They are also bulky for their caloric content like most fruits and vegetables (Benkee \& Sharma 2013). There is evidence that apples possess phenolic compounds, which may be cancer-protective and demonstrate antioxidant activity (Benkee \& Sharma 2013). Apple trees are susceptible to a number of fungal and bacterial diseases and insect pests (Sani et al. 2018). Many commercial orchards pursue a program of chemical sprays to maintain high fruit quality, tree health, and high yields.

Banana is botanically known as Musa sapientum, which makes up the genus Musa of the family Musaceae. It is native to South \& East Asia but is currently cultivated extensively in all tropical countries for their fruit, fibre or foliage. The commercial bananas are mutants of wild Musa species, which produce seedless, and therefore edible, fruits (Keys 1995, Cha et al. 2001). Bananas are the best sources of potassium, an essential mineral for maintaining normal blood pressure, heart function, reducing the risk of stroke, and maintaining body fluid and electrolyte balance in the cell (Sampath-Kumar et al. 2012).

The United States Food and Drug Administration has allowed the banana industry to make official claims for the fruit's ability to reduce the risk of blood pressure and stroke. According to the Food and Drug Administration, diets containing foods that are good sources of potassium and low in sodium may reduce the risk of high blood pressure and stroke (Muhammad et al. 2018). The non-digestible fibres of banana, such as cellulose, hemicellulose and alpha glucans aid to restore regular bowel activity, constipation and diarrhoea (Muhammad et al. 2018). It also normalizes the colon's function to absorb large amounts of water for regular bowel movements due to their richness in pectin. Bananas are an exceptionally rich source of fructooligosaccharide which nourishes probiotic (friendly bacteria) that are found in the colon and produce vitamins and digestive enzymes. The probiotic bacteria protect us against unfriendly microorganisms and also cause fermentation of fructooligosaccharides, which lead to an increase in the number of probiotic bacteria and help in the absorption of calcium (Amusa et al. 2002, Sampath-Kumar et al. 2012). 
Bananas have long been recognized for their antacid effects that protect against stomach ulcers and ulcer damage. Flavonoid and leucocyanidin have been found to significantly increase the thickness of the mucous membrane layer of the stomach (Emim et al. 1994). Banana was found to neutralize acidity, which gets rid of heartburn and has cholesterol-lowering effect (MOI 2008, Sampath-Kumar et al. 2012). Studies conducted on animal indicated that banana has the potential to lower cholesterol (Sastra-Hidayat 1992). It was suggested that the dietary fibre component in banana pulp was responsible for its cholesterol-lowering effect. The amount of dietary fibre in banana is relatively constant during banana ripening (Sastra-Hidayat 1992, Udo \& Mamman 1993, Sampath-Kumar et al. 2012). Bananas promote an overall improvement of the functional efficiency of kidneys (Sampath-Kumar et al. 2012). Benefits to the kidneys are again due to the high potassium content of bananas. A normal intake of potassium suppresses calcium excretion in the urine and minimizes the risk of kidney stones (Sampath-Kumar et al. 2012, Muhammad et al. 2018).

Bananas contain three natural sugars-sucrose, fructose and glucose combined with fibre, which serves as an energy booster. Potassium is essential for muscles to contract properly during exercise and reduces cramping up (Muhammmad et al. 2018). A banana gives an instant, sustained and substantial boost of energy (Sampath-Kumar et al. 2012). Research has proven that just two bananas provide enough energy for a strenuous 90-minute workout (Sampath-Kumar et al. 2012). Acting as an immunity booster, bananas contain $25 \%$ of the recommended daily allowance for vitamin B6 necessary for producing antibodies and red blood cells, as well as aiding in the metabolism of fat. In addition, vitamin B6 serves as an immunity booster. So, this fruit strengthens your armor against infectious diseases. With each average-sized banana, you ingest about $15 \%$ of the recommended daily allowance for vitamin $\mathrm{C}$, one of the strongest antioxidants (SampathKumar et al. 2012).

Fungal attack on fruits may occur during the growing season, harvesting, transport and postharvest storage and marketing conditions, or after purchase by the consumer, causing a change in the taste, smell, appearance or texture, reducing or losing its economic and nutritional value. It was estimated that about $20-25 \%$ of the harvested fruits got decayed by pathogens during post-harvest handling even in developed countries (Droby 2006, Zhu 2006, Sani et al. 2018). In developing countries, post-harvest losses are often more severe due to inadequate storage and transportation facilities. A study conducted by Muhammad et al. (2018) revealed that the most predominant fungi isolated from sweet orange were Cladosporium spp. (40\%), Fusarium spp. (30\%), Alternaria spp. (20\%) and Chrysonilia spp. (10\%) while the most predominant fungi isolated from banana was Fusarium spp. (50\%), Mucor spp. (30\%) and Rhizopus spp. (20\%). Another study conducted by Thiyam \& Sharma (2013) indicated that Acremonium, Alternaria, Aspergillus, Chalaropsis, Cladosporium, Curvularia, Fusarium, Mucor, Penicillium, Rhizopus, and Trichoderma species were isolated from fruit samples. Among the fungal isolates, Aspergillus was found to be the most dominant ones responsible for extensive damage of fruits. In a similar study carried out by AlHindi et al. (2011), the result indicated these fungi to attack the corresponding fruits viz: Fusarium oxysporum (banana and grape), Aspergillus japonicus (pokhara and apricot), Aspergillus oryzae (orange), Aspergillus awamori (lemon), Aspergillus phoenicis (tomato), Aspergillus tubingensis (peach), Aspergillus niger (apple), Aspergillus flavus (mango), Aspergillus foetidus (kiwi) and Rhizopus stolonifer (date). Generally, fungi causing spoilage of fruits are considered toxigenic or pathogenic. During refrigeration, some moulds may produce mycotoxins (Tournas \& Stack 2001). Pathogenic fungi, on the other hand, could cause infections or allergies (Monso 2004). Aspergillus spp. are known to produce several toxic metabolites, such as malformins, naphthopyrones and they can produce ochratoxins, a mycotoxin, which is a very important toxin worldwide because of the hazard it poses to human and animal health (Petzinger \& Weidenbach 2002). The study geared toward isolation and characterization of fungi species associated with some selected fruits sold in Gashua markets, Nigeria. 


\section{Materials and Methods}

\section{Study Area}

The study was conducted in the Department of Biological Science at the Federal University, Gashua. Gashua is a community in Yobe State located in the North-Eastern part of Nigeria on the River Yobe, a few miles below the convergence of the Hadejia River and the Jama'are River. Gashua occupies a land area of 809.661 square kilometers with an average elevation of $299 \mathrm{~m}$ and population of 198, 400 (NPC 2010). Its geographical coordinates are $12^{\circ} 52^{\prime} 05^{\prime \prime} \mathrm{N}$ and $11^{\circ} 02^{\prime} 47^{\prime \prime} \mathrm{E}$. It is located in the Sudan Savanna ecological zone of Nigeria with a form of Sahel Savannah vegetation made up of majorly open thorny shrubs, trees and grasses. The climate is characterized by high temperature and seasonal rainfall. The mean minimum temperature ranges between 10$12^{\circ} \mathrm{C}$ in December-January while the mean maximum is about $34-37^{\circ} \mathrm{C}$ in March-May. The mean rainfall is between $300-500 \mathrm{~mm}$ per annum. The raining season starts from June and lasts until September, while the dry season starts from October and ends in May (NEAZDP, 2015). Agriculture is the prime occupation for Gashua people.

\section{Sample Collection}

From three different markets in Gashua, three different fruits, namely apple, banana and orange, with deteriorated appearances were randomly collected into polythene bags. A total of forty-five (45) fruits with a proportion of fifteen (five oranges, five bananas and five apples) from each market were labeled and transported to the laboratory in clean polythene bags for analyses.

\section{Preparation of Culture Medium for Isolation of Fungi}

Potato Dextrose Agar (PDA) was used for the isolation of fungi and was prepared according to the manufacturer's instruction. The molten medium was poured into conical flasks, plugged with aluminum foil. The medium was sterilized by autoclaving at $121^{\circ} \mathrm{C}$ at a pressure of 15 pounds for 15 minutes. After sterilization, $15 \mathrm{ml}$ of the medium was aseptically dispensed into sterile petri dishes and allowed to solidify. The petri dishes were replicated and labeled accordingly.

\section{Isolation of Fungi}

The samples were brought to the laboratory in separate sterilized polythene bags. Isolation was carried out as described by Baiyewu et al. (2007). The sampled fruits were surface sterilized for 3 minutes with $1 \%$ Sodium hypochlorite and rinsed using sterile distilled running water three times. The surface sterilized fruits showing symptoms of diseases were then sliced into $3-5 \mathrm{~cm}$ using sterilized blade and plated on a Potato Dextrose Agar in a petri dishes which was replicated three times and were labeled accordingly. The plates were incubated in an inverted position at 26$30^{\circ} \mathrm{C}$ for 5-7 days.

\section{Identification of Fungi}

Isolated fungi were identified by examining both macroscopic and microscopic characters. The identification was aided by using the identification keys of Barnett \& Hunter (1972), Klich (2002), Larone (2004), Samson et al. (2004). The identification process was according to Fawole \& Oso (1995). A drop of lactophenol cotton blue stain placed on a clean slide with the aid of a mounted needle and a small portion of the mycelium from the fungal cultures was picked and placed in the drop of the stain. The mycelium was spread very well on the slide with the aid of the two mounted needles, and a cover slip was gently lowered on it. The slide was then examined under the microscope.

\section{Determination of Percentage}

The percentage of the occurrences of different types of isolated fungal contaminants associated with spoilage of apple, banana and orange were calculated using the formula as described by Morsy et al. (2009). 


$$
\text { Percentage of Occurrence }=\frac{\text { Number of Isolated Fungi Species }}{\text { Total Number of Isolates }} \times 100
$$

\section{Result}

A total of eight (8) fungi species were isolated from apple, banana and orange collected from 3 markets in Gashua (Table 1). The isolates were identified by studying their macroscopic and microscopic characters and were compared with already described species using identification keys by Barnett \& Hunter (1972), Klich (2002), Larone (2004), Samson et al. (2004) (Fig. 1, Table 2). The maximum percentage of fungi was noticed in apples as $50 \%$ while banana and orange has the same percentage of $24.99 \%$ each (Table 3). The four (4) fungi species isolated from apple, Aspergillus flavvus, Emercella nidulans, Mucor hiemalis and Rhizopus oligosporus. Among these four (4) fungi species, Mucor hiemalis and Rhizopus oligosporus had the highest percentage with $16.67 \%$ each. The fungi species Acremonium strictum, Eurotium anstelodami and Mucor hemalis were isolated from banana and had the same percentage of $8.33 \%$ each. The three (3) fungi species isolated from orange are Aspergillus fumigatus, Acremonium strictum and Fusarium oxysporum, and each of the fungi species had a percentage of $8.33 \%$ (Table 3). It is evident from Table 3 that Mucor hiemalis and Rhizopus oligosporus had the highest percentage of $16.67 \%$ each out of the eight (8) fungi species isolated from the three (3) fruits.
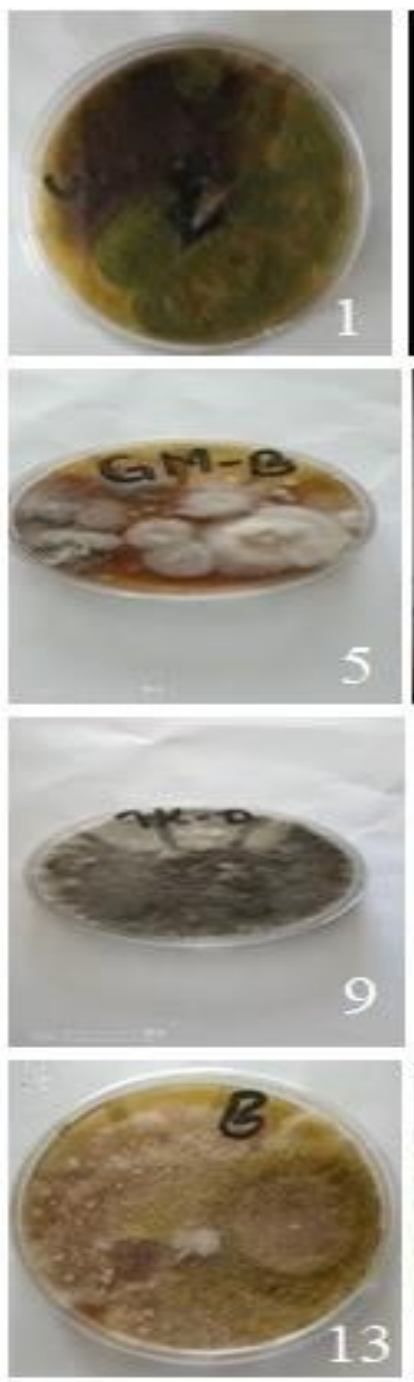
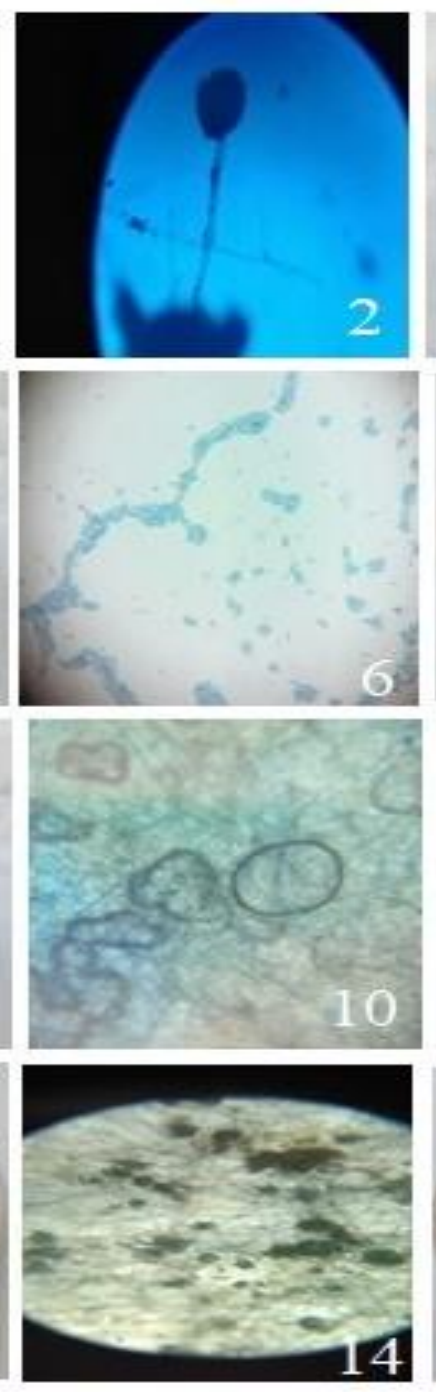
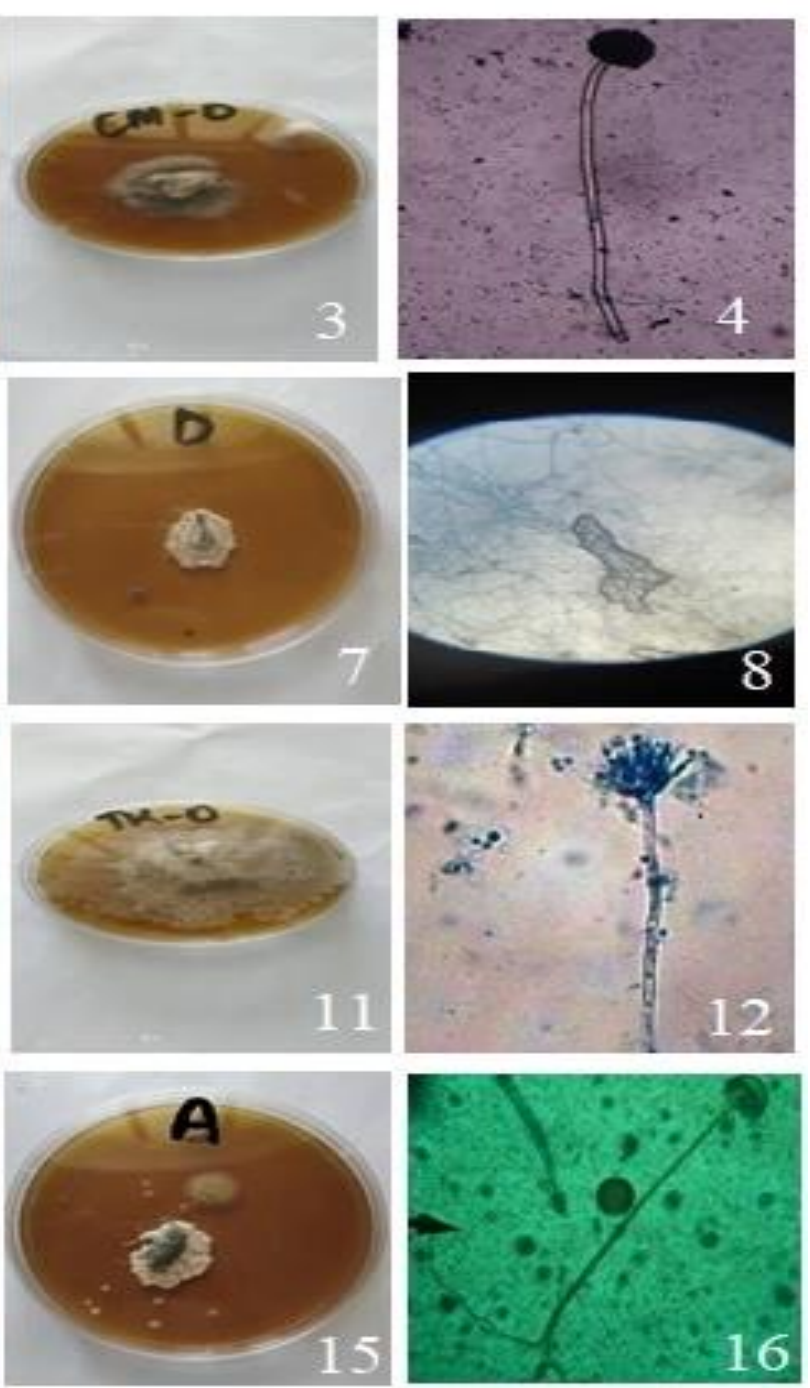

Fig. 1 - Culture plate. 1-2 Aspergillus flavus. 3-4 Aspergillus fumigatus. 5-6 Acremoniun strictum. 7-8 Emercella nidulas. 9-10 Eurotium anstelodami. 11-12 Fusarium oxysporum. 13-14 Mucor hiemalis. 15-16 Rhizopus oligosporus. 
Table 1 Fungi species isolated from three fruits sold in Gashua markets

\begin{tabular}{lccc}
\hline \multicolumn{1}{c}{ Fungal species } & \multicolumn{3}{c}{ Name of Markets } \\
\cline { 2 - 4 } & Gwari Market & Central Market & Tasha Kuka Market \\
\hline Aspergillus flavus & - & - & $\sqrt{ }$ \\
Aspergillus fumigatus & - & $\sqrt{ }$ & - \\
Acremonium strictum & $\sqrt{ }$ & - & - \\
Emercella nidulans & $\sqrt{ }$ & - & $\sqrt{ }$ \\
Eurotium anstelodami & - & - & $\sqrt{ }$ \\
Fusarium oxysporum & - & $\sqrt{ }$ & $\sqrt{ }$ \\
Mucor hiemalis & $\sqrt{ }$ & $\sqrt{ }$ & - \\
Rhizopus oligosporus & $\sqrt{ }$ & & \\
\hline
\end{tabular}

Key: $\sqrt{ }=$ Present, $-=$ Absent

Table 2 Description of the macroscopic and microscopic characteristics of the fungi species

\begin{tabular}{|c|c|c|}
\hline Fungi Species & Macroscopic Characteristics & Microscopic Characteristics \\
\hline Aspergillus flavus & $\begin{array}{l}\text { The upper surface of the colonies } \\
\text { was olive green, white edge, granular } \\
\text { surface and green coloration on the } \\
\text { reverse side on PDA. The Colonies } \\
\text { were ovoid in shape and varied in } \\
\text { size (ranged from } 2.5-3.7 \mathrm{~cm} \text { in } \\
\text { diameter) within } 5 \text { days at room } \\
\text { temperature. }\end{array}$ & $\begin{array}{l}\text { The conidiophore was thick walled, } \\
\text { hyaline and slightly roughened, erect, } \\
\text { long, aseptate with a vesicle at the } \\
\text { top, with phialides, and with short } \\
\text { conidial chains. }\end{array}$ \\
\hline $\begin{array}{l}\text { Aspergillus } \\
\text { fumigatus }\end{array}$ & $\begin{array}{l}\text { The colony was widely spread, dark } \\
\text { green with smooth white edges and } \\
\text { spongy surface and brown on the } \\
\text { reverse side on PDA. The colonies } \\
\text { were round in shape and measured } \\
7 \mathrm{~cm} \text { in diameter within } 5 \text { days at } \\
\text { room temperature. }\end{array}$ & $\begin{array}{l}\text { The conidiophore was long, narrow at } \\
\text { the base and broad near the vesicle, } \\
\text { with smooth-walled hyaline. The } \\
\text { conidial head was greyish near the } \\
\text { apices with an irregular shape. }\end{array}$ \\
\hline $\begin{array}{l}\text { Acremonium } \\
\text { strictum }\end{array}$ & $\begin{array}{l}\text { The upper surface of the colonies } \\
\text { was pink-orange, smooth, and } \\
\text { velvety at the center, and measured } \\
2-3.5 \mathrm{~cm} \text { on PDA within } 7 \text { days, } \\
\text { while the reserve side was whitish } \\
\text { with a smooth edge. }\end{array}$ & $\begin{array}{l}\text { The conidiophore bore branch } \\
\text { phialides arisen from aerial hyphae. } \\
\text { The conidia have a slimy head, } \\
\text { cylindrical in shape. }\end{array}$ \\
\hline Emercella nidulans & $\begin{array}{l}\text { The upper surface of the colony on } \\
\text { PDA measured 5-9cm within } 7 \text { days. } \\
\text { It was velvety, dark yellow-green } \\
\text { shade, brighter at the edge; while the } \\
\text { reverse side was olive to drab-grey. }\end{array}$ & $\begin{array}{l}\text { The conidiophores were tall, with } \\
\text { brown and smooth-walled with } \\
\text { vesicle more globose. The conidial } \\
\text { head was dark yellow-green } \\
\text { columnar, biseriate and rough walled } \\
\text { globose. }\end{array}$ \\
\hline $\begin{array}{l}\text { Eurotium } \\
\text { anstelodami }\end{array}$ & $\begin{array}{l}\text { The colony surface was white, with } \\
\text { brown colouration at the center, and } \\
\text { spongy and smooth at the edge. } \\
\text { Brown with black-white patches at } \\
\text { the center and white edge on the } \\
\text { reverse side on PDA within } 7 \text { days at } \\
\text { room temperature, and measured 4- } \\
6 \mathrm{~cm}\end{array}$ & $\begin{array}{l}\text { The hyphae are hyaline, branched, } \\
\text { bear the conidiophores on aerial } \\
\text { branches. The conidia head is olive } \\
\text { green, tall vesicle globose and } \\
\text { echinulate. }\end{array}$ \\
\hline
\end{tabular}


Table 2 Continued.

\begin{tabular}{|c|c|c|}
\hline Fungi Species & Macroscopic Characteristics & Microscopic Characteristics \\
\hline $\begin{array}{l}\text { Fusarium } \\
\text { oxysporum }\end{array}$ & $\begin{array}{l}\text { The colony was pink with a white } \\
\text { patch on the surface and on the } \\
\text { reverse side was brown in coloration } \\
\text { on PDA. The colony was round in } \\
\text { shape and measured } 4 \mathrm{~cm} \text { in diameter } \\
\text { within } 5 \text { days at room temperature. }\end{array}$ & $\begin{array}{l}\text { The macroconidia are canoe-shaped, } \\
\text { multi-septate, contain } 3-6 \text { septations } \\
\text { and slightly pointed at the end. The } \\
\text { microconidia are ovoid or oblong } \\
\text { borne single with no septation and } \\
\text { single-celled. }\end{array}$ \\
\hline Mucor hiemalis & $\begin{array}{l}\text { White surface with brown at the } \\
\text { center, spongy in nature with smooth } \\
\text { edge. It was grayish at the center } \\
\text { with brown and black patches and } \\
\text { white edges on the reserve side. The } \\
\text { colonies measured } 4-7 \mathrm{~cm} \text { on PDA } \\
\text { within } 5 \text { days at room temperature. }\end{array}$ & $\begin{array}{l}\text { The sporangiosphores have terminal } \\
\text { sporangia containing round } \\
\text { sporangiospores, and columella was } \\
\text { well developed with non-septate } \\
\text { hyphae. }\end{array}$ \\
\hline $\begin{array}{l}\text { Rhizopus } \\
\text { oligosporus }\end{array}$ & $\begin{array}{l}\text { Colonies light grey, growing rapidly } \\
\text { and filling the petri dish with dense } \\
\text { cottony mycelium, producing a mass } \\
\text { of sporangia. The colonies measured } \\
8-10 \mathrm{~cm} \text { on PDA within } 5 \text { days at } \\
\text { room temperature. }\end{array}$ & $\begin{array}{l}\text { Large sporangiophores with non- } \\
\text { septate hyphae were formed. }\end{array}$ \\
\hline
\end{tabular}

Table 3 Percentage of occurrence of fungi species isolated from three fruits

\begin{tabular}{llll}
\hline \multicolumn{1}{c}{ Fungal species } & \multicolumn{3}{c}{ Fruits } \\
\cline { 2 - 4 } & \multicolumn{1}{c}{ Apple } & Banana & Orange \\
\hline Aspergillus flavus & $1(8.33 \%)$ & $0(0.00 \%)$ & $0(0.00 \%)$ \\
Aspergillus fumigatus & $0(0.00 \%)$ & $0(0.00 \%)$ & $1(8.33 \%)$ \\
Acremonium strictum & $0(0.00 \%)$ & $1(8.33 \%)$ & $1(8.33 \%)$ \\
Emercella nidulans & $1(8.33 \%)$ & $0(0.00 \%)$ & $0(0.00 \%)$ \\
Eurotium anstelodami & $0(0.00 \%)$ & $1(8.33 \%)$ & $0(0.00 \%)$ \\
Fusarium oxysporum & $0(0.00 \%)$ & $0(0.00 \%)$ & $1(8.33 \%)$ \\
Mucor hiemalis & $2(16.67 \%)$ & $1(8.33 \%)$ & $0(0.00 \%)$ \\
Rhizopus oligosporus & $2(16.67 \%)$ & $0(0.00 \%)$ & $0(0.00 \%)$ \\
Maximum Occurrence & $6(50.00 \%)$ & $3(24.99 \%)$ & $3(24.99 \%)$ \\
\hline
\end{tabular}

\section{Discussion}

The result derived from this study revealed the presence of eight (8) fungi species from the deteriorated fruits collected from three (3) markets in Gashua. Previous studies revealed that these fungal species are the causative agents of fruits' spoilage during post-harvest in developing countries like Nigeria (Droby 2006). The results suggested that the maximum occurrence of fungi in fruits was noticed in apples with 50\% while banana and orange has the same percentage of $24.99 \%$ each. The high percentage of contamination of apple by fungal species could be attributed to poor hygiene during handling and high exposure to environmental condition or contaminants, considering the fact that, most of the apple sold in the market in Nigerian are been imported. This finding collaborated with the result obtained by Zahra (2016), who reported that the maximum percentage of fungi in fruits was noticed in apple followed by banana and orange. The four (4) fungi species isolated from apple are Aspergillus flavvus, Emercella nidulans, Mucor hiemalis and Rhizopus oligosporus. Among these four (4) fungi species, Mucor hiemalis and Rhizopus oligosporus had the highest percentage of $16.67 \%$ each. The occurrence of Aspergillus flavvus, Emercell anidulans, Mucor hiemalis and Rhizopus oligosporus in the apples could be attributed to 
their ability to tolerate wide ranges of temperature and $\mathrm{pH}$, and thrive in environments with limited nutrient, which coupled with poor storage and handling, and their ability to secrete the pigment called melanin, which provides protection against a range of stresses, makes them resistant to environmental factors such as temperature (Waipara 1998, Langfelder et al. 2003). This finding is in agreement with the results reported by Bashar et al. (2012) and Mairami et al. (2019).

The three fungal species isolated from banana are Acremonium strictum, Eurotium anstelodami and Mucor hemalis while Aspergillus fumigatus, Acremonium strictum and Fusarium oxysporum were isolated from orange, both the fungi isolated from banana and orange recorded a percentage of $8.33 \%$ each. The occurrence of these fungal species in the bananas and oranges could be attributed to poor management, coupled with poor hygiene, poor handling and poor storage. This finding is in agreement with the result reported by Sani et al. (2018). According to Thliza et al. (2015), the occurrence of these fungi may cause diverse effects on human health as they have the potential of producing mycotoxins which could be hazardous to human health and other animals. Some of the fungal species are capable of producing aflatoxins, cyclopiazonic acid, fumitremorgin, gliotoxin, nidulotoxin nitropropionic acid, ochratoxins, penicillin, sterigmatocystin and verrucologen, which are carcinogenic and are capable of causing kidney and liver disorders, invasive and non-invasive aspergillosis, allergy and sinusitis (Bryce 1999, Bennett \& Klich 2003, Samson et al. 2004).

\section{Acknowledgements}

We are grateful to the Department of Biological Science, Federal University, Gashua, Nigeria for providing the basic materials that were used for the analysis; and the staff for their technical support in the laboratory.

\section{Reference}

Al-Hindi RR, Al-Najada AR, Mohamed SA. 2011 - Isolation and identification of some fruit spoilage fungi: Screening of plant cell wall degrading enzymes. African Journal of Microbiology Research 5, 443-448.

Amusa NA, Kehinde IA, Ashaye OA. 2002 - Bio-deterioration of bread fruit (Artocrarpus communis) in storage and its effects on the nutrient composition. African Journal of Biotechnology 1, 57-60.

Baiyewu RA, Amusa NA, Ayoola OA, Babalola OO. 2007 - Survey of the postharvest diseases and aflatoxin contamination of marketed Pawpaw fruit (Carica papaya L.) in South Western Nigeria. African Journal of Agriculture Research 2, 178-181.

Benkee T, Sharma GD. 2013 - Isolation and Identification of Fungi Associated with Local Fruits of Barak Valley, Assam. Current World Environment 8, 319-322.

Barnett HL, Hunter BB. 1972 - Illustrated Genera of Imperfect Fungi. $4^{\text {th }}$ edition, Macnuilian Publishing Co., New York. Pp. 320.

Bashar MA, Shamsi S, Hossain M. 2012 - Fungi associated with rotten fruits in Dhaka Metropolis. Bangladesh. Journal of Botany 41, 115-117.

Bennett JW, Klich M. 2003 - Mycotoxins. Clinicla Microbiology Review 16, 497-516.

Bernardi J, Licciardello C, Russo MP. 2010 - Use of a custom array to study differentially expressed genes during blood orange (Citrus sinensis L. Osbeck) ripening. Journal of Plant Physiology 167, 301-310.

Boyer R. 2009 - Using dehydration to preserve fruits, vegetables, and meats. Issued in furtherance of cooperative extension work. Virginia Polytechnic Institute and State University, Virginia State University, and the U.S. Department of Agriculture Cooperating. Edwin J. Jones, Director, Virginia Cooperative Extension, Virginia Tech, Blacksburg; M. Ray McKinnie, Interim Administrator, 1890 Extension Program, Virginia State University, Petersburg. Pp. 348-597. 
Bryce K. 1999 - The Fifth Kingdom Third Edition. Published by Focus Publishing R. Pullins CO. Canada. Pp. 303-315.

Cha JY, Cho YS, Kim I. 2001 - Effect of hesperetin, a citrus flavonoid on the liver triacylglycerol content and phosphatidatephosphohydrolase activity in orotic acid-fed rats. Plant Foods for Human Nutrition 56, 349-358.

Danila D, Marco G, Maurizio L. 2005 - Flavanones in citrus fruit: Structure antioxidant activity relationships. Food Research International 38, 1161-1166.

Dhandevi P, Rajesh J. 2015 - Fruit and vegetable intake: Benefits and progress of nutrition education interventions-narrative review article. Iran Journal of Public Health 44, 1309-1321.

Droby S. 2006 - Improving quality and safety of fresh fruits and vegetables after harvest by the use of biocontrol agents and natural materials. Acta Horticulture 709, 45-51.

ElSayed IA, Edrees NO. 2014 - Using of plant growth promoting rhizobacteria as biocontrol agent for root knot nematode under greenhouse. Nature and Science 12, 1-12.

Emim JA, Oliveira AB, Lapa AJ. 1994 - Pharmacological evaluation of the anti-inflammatory activity of a citrus bioflavonoid, hesperidin, and the isoflavonoids, duartin and claussequinone, in rats and mice. Journal of Pharmacy and Pharmacology 46, 118-122.

Fawole MO, Oso BA. 1995 - Laboratory Manual of Microbiology. $1^{\text {st }}$ edition. Nigeria: Spectrum Books Ltd, Ibadan, Pp. 34-35.

Guo WW, Deng XX. 2001 - Wide somatic hybrids of Citrus with its related genera and their potential in genetic improvement. Euphytica 118, 175-183.

Goudeau D, Uratsu S, Inoue K. 2008 - Tuning the orchestra: Selective gene regulation and orange fruit quality. Plant Science 174, 310-320.

Keys A. 1995 - Mediterranean diet and public health: Personal reflections. American Journal of Clinical Nutrition 61, 1321-1323.

Klich AM. 2002 - Identification of Common Aspergillus species. Published by the Centraal Bureau VoorSchimmelcultures, Utrecht. Pp 1-115.

Langfelder K, Streibel M, Jahn B, Haase G, Brakhage AA. 2003 - Biosynthesis of fungal melanins and their importance for human pathogenic fungi. Fungal Genetics and Biology 38, 143-158.

Larone DH. 2004 - Medically Important Fungi: A Guide to Identification. ASM press, Washington D.C. 23-234.

Manthey JA, Grohmann K, Guthrie N. 2001 - Biological properties of citrus flavonoids pertaining to cancer and inflammation. Current Medicine and Chemical 8, 135-153.

Mairami FM, Ndana R, Umar ID, Nura S. 2019 - Isolation and characterization of fungal species from spoilt fruits in Utako Market, Abuja, Nigeria. Journal of Applied Science 19, 15-19.

Morsy ME, El-Dohlob SM, Hyde KD. 2009 - Diversity ofAlternaria alternataa common destructive pathogen of Eichhornia crassipesin Egypt and its potential use in bio-logical control. Fungal Diver 23, 139-158.

MOI. 2008 - Ministry of Information. Sokoto, Nigeria: Diary; 2008. 12 p. 70.

Monso EM. 2004 - Occupational asthma in greenhouse workers. Current Opinion in Pulmonary Medicine, 10: 147-150.

Muhammad AS, Mohammed IU, Ameh M. 2018 - Isolation and identification of fungi associated with the spoilage of sweet orange (Citrus sinensis L) and banana (Musa sapientum L) in Sokoto Metropolis. Journal of Applied Biotechnology and Bioengineering 5, 172-182.

NPC. 2010 - Population Distribution by Sex, State, LGA and Senatorial Districts, Pp 34. NPC (National Population Commission): www.population.gov.ng (Accessed on May 14, 2017

NEAZDP. 2015 - Meteorological Data of Nine Local Government Areas in Northern Yobe State, 1992-2014. NEAZDP (North East Arid Zone Development Programme) Hydromet Station, Garin Alkali. 
Obeta SE, Nwakonobi TU, Adikwu OA. 2011 - Microbial effect of selected stored fruits and vegetables under ambient conditions in Makurdi, Benue State, Nigeria. Research Journal of Applied Science and Engineering Technology, 3(5): 393-398.

Piccinelli AL, García MM, Armenteros DM. 2008 - HPLC-PDA-MS and NMR Characterization of C-Glycosyl Flavones in a Hydroalcoholic Extract of Citrus aurantifolia Leaves with Antiplatelet Activity. Journal Agriculture, Food and Chemical 56, 1574-1581.

Petzinger E, Weidenbach A. 2002 - Mycotoxins in the food chain: The role of ochratoxins. Livestock Production Science 76, 245-250.

Rickman JC, Barett DM, Bruhn CM. 2007 - Nutritional comparison of fresh, frozen and canned fruits and vegetables. Vitamin C, B and phenolic compounds. Journal of the Science of Food and Agriculture 14, 345-354.

Sampath-Kumar KP, Debjit B, Duraivel S, Umadevi M. 2012 - Traditional and medicinal uses of banana. Journal of Pharmacognosy and Phytochemistry 1, 51-63.

Samson AR, Hoekstra SE, Prisvad CJ. 2004 - Introduction to Food and Airborne Fungi, Seventh Edition. Published by the Centraal Bureau VoorSchimmelcultures, Utrecht. Pp. 12-124.

Sani NM, Salihu Y, Saidu AY, Yusouf S et al. 2018 - Isolation of fungi associated with spoilage of selected vegetables sold in Dutse-Ultra-Modern Market, Jigawa State, Nigeria. Dutse Journal of Pure and Applied Sciences 4, 350-356.

Sastra-Hidayat AR. 1992 - Preliminary epidemiological study of powdery mildew (Oidiumtingitaninum) on Citrus sinensis. Indonesian Center for Agricultural Library and Technology Dissemination, Pusat Perpustakaandan Penyebaran Teknologi Pertanian (Indonesia) ICALTD Asian citrus rehabilitation conference. Indonesia: Malang. Pp. 1-10.

Sinclair WB, Bartholomew ET, Ramsey RC. 1945 - Analysis of the organic acids of orange juice. Plant Physiology 20, 3-18.

Sohail E, Ahmed E, Kiku M. 2006 - Limonoids as cancer chemopreventive agents. Journal of the Science of Food and Agriculture 86, 339-345.

Thiyam B, Sharma GD. 2013 - Isolation and identification of fungi associated with local fruits of Barak Valley, Assam. Current World Environment 8, 319-322.

Thliza IA, Khan AU, Dangora DB. 2015 - Fungi contamination of some selected brands of sachet water marketed in Ahmadu Bello University, Zaria, Nigeria. Journal of Microbiology Research 5, 23-30.

Tournas VH, Stack ME. 2011 - Production of alternariol and alternariol methyl ether by alternariaalternata grown on fruits at various temperatures. Journal of Food Protection 64, 528-532.

Tripoli E, LaGuardia M, Giammanco S. 2007 - Citrus flavonoids: Molecular structure, biological activity and nutritional properties: A Review. Journal Food Chemistry 104, 466-479.

Udo RK, Mamman AB. 1993 - Giant in the tropics. State Surveys. Pp. 435-446.Isolation and identification of fungi associated with fruits sold in local markets. International Journal of Research Studies in Biosciences 4, 61-64.

USDA-APHIS. 2010 - Non-Chemical Treatment-Cold Treatment. United States Department of Agriculture, Animal and Plant Health Inspectionn Service, Plant Protection Quarantine, Riverdale. Pp. 1-7.

Waipara NW. 1998 - A Method to Assess the Lethal Effect of UV-C Irradiation of Fungal Spores on a Dry Surface. National Veterinary Institute, Oslo 12-33.

Zahra IE. 2016 - Isolation and Identification of Fungi Associated with Fruits Sold in Local Markets. International Journal of Research Studies in Biosciences 4, 61-64.

Zhu SJ. 2006 - Non-chemical approaches to decay control in postharvest fruit. In: Noureddine, B. and Norio, S., editors. Advances in Postharvest Technologies for Horticultural Crops. Research Signpost, Trivandrum, India. Pp. 297-313. 